DOI: 10.20472/IAC.2018.036.039

KIRAN PRAJAPATI

Sheth R A College of Science, India

\title{
STUDIES OF PHYSICO-CHEMICAL CHARACTERISTICS OF SURFACE WATER AT THE VICINITY OF NAROL INDUSTRIAL AREA, AHMEDABAD, GUJARAT
}

\begin{abstract}
:
Industrial area in Narol, is located in the outskirt region of Ahmedabad, Gujarat with a number of industries. Chemicals and textile industries are an important industry in this area producing a number of agrochemicals and cloths along with lot of effluents throughout the year. The accumulated effluents bring about changes in the various water quality parameters. The study of surface water quality at the vicinity of industrial area throughout the year 2015 (during monsoon, pre-monsoon and post- monsoon period) reveals that all the water quality parameters specially $\mathrm{pH}$ and fluoride content are much above the standard values prescribed by ISO 10500 which gradually approach towards standard value with an increase in distance from the industry. The surface water up to a distance of $02 \mathrm{~km}$ from core industrial area is not suitable for living organisms.
\end{abstract}

\section{Keywords:}

Industrial pollution, Water quality parameters, pH Fluoride content 


\section{INTRODUCTION:}

In the recent years environmental monitoring through regular assessment of water quality has become a crucial factor in the exploitation or conservation of aquatic resources. [6] Water the most vital abiotic component and unique in many respects; occurs in all the three states (solid, liquid and gaseous) on the earth. In recent trend like rapid industrialization, more or less unplanned urbanization, where in residential and industrial area coexists etc. discharge a lot of effluents into environment causing water pollution.

[2] Narol is situated at a latitude $22^{\circ} 58^{\prime} \mathrm{N}$ and a longitude $72^{\circ} 35^{\prime} \mathrm{E}$ at the outskirt of Ahmedabad city of Gujarat State, India. It is a growing industrial zone with a sizable population. The Narol Industrial Cluster is spread over an area of about 500 hectares in Narol, Shahwadi, Isanpur and Piplaj areas in Ahmedabad district and fall under the Ahmedabad Municipal Corporation limits. River Sabarmati flows towards West while industrial area is located towards East. Towards its North is the Ahmedabad city while to the South is the villages of Lambha and Jetalpur (Fig.1). Narol Industrial Cluster is an agglomerate of 224 industries engaged in mainly dyeing and processing of textiles and dyes \& chemicals. The members of Narol Industrial Cluster process about 2800 million meters of fabric every year and Dyes \& chemicals. This cluster mainly comprises of textile processing and dyes \& chemical units. Hence major probable pollutants are BOD, COD, Color, TDS, Ammonical Nitrogen, Phenolic compound etc (GPCB, Gandhinagar 2010).

The major industries located and contribute quality of water at Narol includes Girnar Enterprise, Pious Industries, Texmo industries, Mukesh industries, Arfat Textile, Shree Gopal creation, Balkrishna Textile, Mahodari Textile, M J Chemicals, Arti chemical industry, Vimal Chemicals, Tara Enterprise, Shree Ganesh Enterprise, Ajanta Chemicals, Samrat Enterprise, Zydex industries, A K Dye Chem, Karnavati Chemicals Factory, Gayatri Enterprise, Chemizone India, Komal Industries, Roopdhara Industries, Kadam Dyes \& Intermediates, Satyam Chemical Industries Private Limited, Anjali Colors, Dhariyal Polymers Pvt Ltd. Bhavani Dye Chem, Neel Chem India, Shyam Enterprise, Hardik Chemical Industries, Galaxy Colchem Pvt Ltd, Agma Agencies, Hans Traders, School Dyes \& Chemicals, Nisha Chemicals, Poonam Chemical Industries, Sachin Dye Chem, Crown industries, Truetzscher Industries Pvt Ltd and Stovek Industries Limited etc. All industries together release a lot of effluents throughout the year which are either accumulated at specific sites or discharged into water bodies. The major inhabitants of this area depend on the surface water mainly ponds and in some places wells. The discharge of effluents from various industries in this area (partly treated or untreated) causes depletion of water quality of the area inducing a number of water-borne and skin diseases.

The textile industry is one of the leading sectors in the Indian economy as it contributes nearly 14 percent to the total industrial production 
(business.mapsofindia.com). The untreated textile wastewater can cause rapid depletion of dissolved oxygen if it is directly discharged into the surface water sources due to its high BOD value. The effluents with high levels of BOD and COD values are highly toxic to biological life. The high alkalinity and traces of chromium which is employed in dyes adversely affect the aquatic life also textile processing units contains a complex mixture of dyes. The textile industry uses high volume of water throughout its operation, from the washing of fibers to bleaching, mercerizing, dyeing, and printing and washing of finished products. All these processes release a lot of extraneous matter and energy to the environment causing pollution of all kind. Out of all types of pollutions, water pollution draws the attention of civilized society because it is responsible for the occurrence of a number of diseases causing health hazards. That's why environmental monitoring through water quality assessment should be a continuous process and regularly undertaken. [3] Assessment of pollution influence and overall conservation of an ecosystem are essential. The quality of industrial effluent can be analyzed by their physico-chemical and biological analysis. Monitoring of the environmental parameters of the effluent would allow having, at any time, a precise idea on quality of water around so necessary, appropriate measures may be undertaken to prevent adverse impact on environment.

In the present work, an attempt has been made to study the seasonal variations in the physico-chemical characteristics of surface water at the vicinity of core industrial zone up to a distance of $4 \mathrm{~km}$ (Table 1). The water quality is monitored by studying the changes in parameters like pH, TDS, Conductivity, DO, BOD, COD, T.H., Mg. H, Ca. $\mathrm{H}$, Alkalinity, Chloride, Fluoride, Nitrate Nitrogen, Turbidity etc.

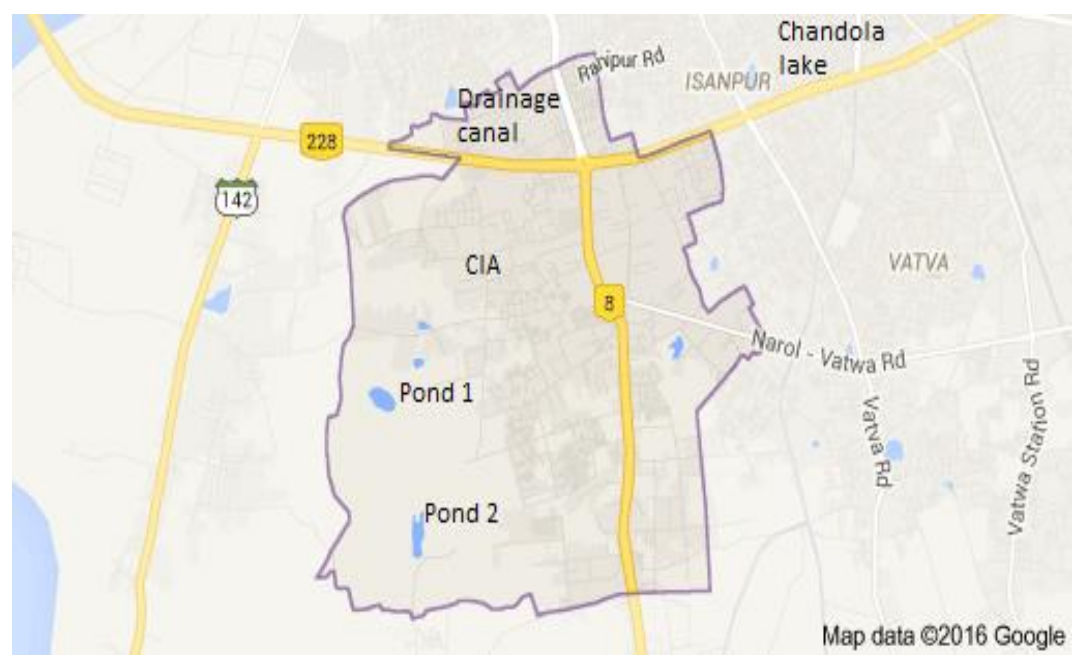

Fig.1 Study area 


\section{MATERIALS AND METHODS:}

\section{Sample Collection}

The water samples have been collected from different places from the core industrial establishments within a radius of $4 \mathrm{~km}$. For monitoring and analysis, the sampling location was identified and the samples be analyzed were decided. Generally, textile wet processing industry which is located at Narol, Ahmedabad are mostly small-scale industry \& medium scale industry. They operate their Effluent treatment Plant up to primary treatment or secondary treatment or some may be operate up to tertiary treatment also. At present, the treated effluent from industrial units of this cluster is discharged into mega pipeline and mixed with treated sewage coming from Pirana sewage treatment plant of Ahmedabad Municipal Corporation before final discharge into river Sabarmati. The mega pipeline has, since last few years, carrying excess of capacity and as a result, frequent overflows in upstream locations are being observed posing serious survival questions for water bodies in the vicinity. [4] Prior to sampling the collection bottles have been rinsed well and then filled up to neck and stoppered immediately to prevent any accidental entry or escape as well as interaction with outside atmosphere. In anticipation of possible changes in certain water quality parameters with respect to time $\mathrm{pH}$, temperature, dissolved oxygen (DO) and conductivity have been measured immediately after the collection of samples

\section{Physicochemical Analysis}

The water samples were collected in plastic bottles from each site. [5] For dissolve oxygen water samples were collected in separate BOD bottles and fixed on the spot, the other parameters like $\mathrm{pH}$ and temperature was measured by $\mathrm{pH}$ meter and thermometer respectively. Rest of the physico-chemical parameters such as $\mathrm{pH}$, total dissolved solids (TDS), conductivity, dissolved Oxygen (DO), Biochemical Oxygen Demand (BOD), Chemical Oxygen Demand (COD), Total Hardness (TH), calcium hardness $(\mathrm{CaH})$, alkalinity, chloride and fluoride of the water samples were measured (Table-2). An average of three observations in a season with respect to each monitoring station and parameters has been determined and the results have been compared with the Indian standards (ISO 10500) for potable water. The data given in the Table-2 to 4 are average values of 05 observations were analyzed according to the 'Standard methods for the examination of water and waste water [9] (APHA-1975) and Environmental analysis of water, soil and air ([7] Saxena 1998), [1] Alka L. Gupta (2006) and [8] M.S. Kodarkar et al. (2006). 
Table 1: Different sampling site at Narol

\begin{tabular}{|l|l|c|}
\hline Sr No & \multicolumn{1}{|c|}{ Sample site } & $\begin{array}{c}\text { Distance from core industrial } \\
\text { area }(\mathrm{ClA})\end{array}$ \\
\hline 1 & Pond 1 & $0.6 \mathrm{~km}$ \\
\hline 2 & Drainage canal & $1.7 \mathrm{~km}$ \\
\hline 3 & Pond 2 & $3.0 \mathrm{~km}$ \\
\hline 4 & Chandola lake & $4.0 \mathrm{~km}$ \\
\hline
\end{tabular}

Table.2 Analysis of water quality parameters of pond $1(0.6 \mathrm{~km}$ from CIA)

\begin{tabular}{|c|c|c|c|c|c|}
\hline $\begin{array}{l}\text { Sr } \\
\text { No }\end{array}$ & Parameter & $\begin{array}{c}\text { Standard } \\
\text { as per } \\
\text { ISO } \\
10500\end{array}$ & Monsoon & $\begin{array}{c}\text { Post- } \\
\text { monsoon }\end{array}$ & $\begin{array}{c}\text { Pre- } \\
\text { monsoon }\end{array}$ \\
\hline 1 & $\mathrm{pH}$ & $6.5-8.5$ & 2.86 & 2.03 & 1.88 \\
\hline 2 & TDS & $\begin{array}{l}500- \\
2000\end{array}$ & 2756 & 3150 & 3400 \\
\hline 3 & $\begin{array}{l}\text { Conductivity } \\
\text { (mho/cm) }\end{array}$ & $200-700$ & 2002 & 2064 & 2017 \\
\hline 4 & DO & $4.0-6.0$ & 13.1 & 13.5 & 8.7 \\
\hline 5 & BOD & 30 & 3.3 & 4.1 & 10.0 \\
\hline 6 & COD & 10 & 9.2 & 8.5 & 8.1 \\
\hline 7 & T.H & $300-600$ & 1215 & 1270 & 1300 \\
\hline 8 & Ca.H & $75-200$ & 35 & 32 & 98 \\
\hline 9 & Mg.H & $30-150$ & 23 & 23.8 & 110 \\
\hline 10 & Alkalinity & $200-600$ & 70 & 69 & 102 \\
\hline 11 & Chloride & $\begin{array}{l}250- \\
1000\end{array}$ & 6245 & 6321 & 7745 \\
\hline 12 & Fluoride & $1.0-1.5$ & 6.4 & 8.2 & 10.2 \\
\hline 13 & Nitrate Nitrogen & $45-1000$ & 203 & 278 & 350 \\
\hline
\end{tabular}

Table.3 Analysis of water quality parameters of drainage canal (1.7 km from CIA)

\begin{tabular}{|c|c|c|c|c|c|}
\hline $\begin{array}{l}\text { Sr } \\
\text { No }\end{array}$ & Parameter & $\begin{array}{c}\text { Standard } \\
\text { as per } \\
\text { ISO } \\
10500\end{array}$ & Monsoon & $\begin{array}{c}\text { Post- } \\
\text { monsoon }\end{array}$ & $\begin{array}{c}\text { Pre- } \\
\text { monsoon }\end{array}$ \\
\hline 1 & $\mathrm{pH}$ & $6.5-8.5$ & 6.80 & 6.05 & 5.36 \\
\hline 2 & TDS & $\begin{array}{l}500- \\
2000\end{array}$ & 233 & 256 & 262 \\
\hline 3 & $\begin{array}{l}\text { Conductivity } \\
\text { (mho/cm) }\end{array}$ & $200-700$ & 601 & 612 & 603 \\
\hline 4 & DO & $4.0-6.0$ & 11.5 & 12 & 11 \\
\hline 5 & BOD & 30 & 8.7 & 9.2 & 8.6 \\
\hline 6 & COD & 10 & 6.3 & 6.8 & 6.9 \\
\hline 7 & T.H & $300-600$ & 1103 & 1170 & 1181 \\
\hline
\end{tabular}




\begin{tabular}{|c|l|c|c|c|c|}
\hline 8 & Ca.H & $75-200$ & 258 & 242 & 270 \\
\hline 9 & Mg.H & $30-150$ & 173 & 188 & 199 \\
\hline 10 & Alkalinity & $200-600$ & 354 & 377 & 401 \\
\hline 11 & Chloride & $250-$ & 198 & 206 & 213 \\
& & 1000 & & & \\
\hline 12 & Fluoride & $1.0-1.5$ & 6.1 & 6.4 & 8.3 \\
\hline 13 & Nitrate Nitrogen & $45-1000$ & 156 & 162 & 170 \\
\hline
\end{tabular}

Table.4 Analysis of water quality parameters of pond $2(3 \mathrm{~km}$ from CIA $)$

\begin{tabular}{|c|c|c|c|c|c|}
\hline $\begin{array}{l}\mathrm{Sr} \\
\text { No }\end{array}$ & Parameter & $\begin{array}{c}\text { Standard } \\
\text { as per } \\
\text { ISO } \\
10500\end{array}$ & Monsoon & $\begin{array}{c}\text { Post- } \\
\text { monsoon }\end{array}$ & $\begin{array}{c}\text { Pre- } \\
\text { monsoon }\end{array}$ \\
\hline 1 & $\mathrm{pH}$ & $6.5-8.5$ & 7.50 & 7.30 & 7.40 \\
\hline 2 & TDS & $\begin{array}{l}500- \\
2000\end{array}$ & 403 & 424 & 443 \\
\hline 3 & $\begin{array}{l}\text { Conductivity } \\
\text { (mho/cm) }\end{array}$ & $200-700$ & 756 & 762 & 767 \\
\hline 4 & DO & $4.0-6.0$ & 7.9 & 7.8 & 7.5 \\
\hline 5 & BOD & 30 & 8.3 & 8.6 & 8.9 \\
\hline 6 & COD & 10 & 7.1 & 7.4 & 7.7 \\
\hline 7 & T.H & $300-600$ & 530 & 540 & 548 \\
\hline 8 & Ca.H & $75-200$ & 254 & 262 & 270 \\
\hline 9 & Mg.H & $30-150$ & 64 & 78 & 89 \\
\hline 10 & Alkalinity & $200-600$ & 530 & 544 & 566 \\
\hline 11 & Chloride & $\begin{array}{l}250- \\
1000\end{array}$ & 270 & 274 & 288 \\
\hline 12 & Fluoride & $1.0-1.5$ & 5.8 & 6.01 & 6.23 \\
\hline 13 & Nitrate Nitrogen & $45-1000$ & 162 & 171 & 182 \\
\hline
\end{tabular}

Table.5 Analysis of water quality parameters of Chandola Lake ( $4 \mathrm{~km}$ from CIA)

\begin{tabular}{|c|c|c|c|c|c|}
\hline $\begin{array}{l}\mathrm{Sr} \\
\text { No }\end{array}$ & Parameter & $\begin{array}{c}\text { Standard } \\
\text { as per } \\
\text { ISO } \\
10500\end{array}$ & Monsoon & $\begin{array}{c}\text { Post- } \\
\text { monsoon }\end{array}$ & $\begin{array}{c}\text { Pre- } \\
\text { monsoon }\end{array}$ \\
\hline 1 & $\mathrm{pH}$ & $6.5-8.5$ & 7.0 & 7.2 & 7.4 \\
\hline 2 & TDS & $\begin{array}{l}500- \\
2000\end{array}$ & 498 & 502 & 513 \\
\hline 3 & $\begin{array}{l}\text { Conductivity } \\
\text { (mho/cm) }\end{array}$ & $200-700$ & 752 & 760 & 764 \\
\hline 4 & DO & $4.0-6.0$ & 7.8 & 7.7 & 7.9 \\
\hline 5 & BOD & 30 & 9.0 & 9.3 & 10 \\
\hline 6 & COD & 10 & 7.3 & 7.2 & 7.2 \\
\hline 7 & T.H & $300-600$ & 478 & 482 & 487 \\
\hline 8 & Ca.H & $75-200$ & 203 & 245 & 252 \\
\hline
\end{tabular}




\begin{tabular}{|c|c|c|c|c|c|}
\hline 9 & Mg.H & $30-150$ & 62 & 70 & 74 \\
\hline 10 & Alkalinity & $200-600$ & 516 & 522 & 527 \\
\hline 11 & Chloride & $\begin{array}{l}250- \\
1000\end{array}$ & 249 & 261 & 270 \\
\hline 12 & Fluoride & $1.0-1.5$ & 4.8 & 4.9 & 5.0 \\
\hline 13 & Nitrate Nitrogen & $45-1000$ & 160 & 168 & 180 \\
\hline
\end{tabular}

\section{RESULTS AND DISCUSSION:}

The physicochemical characteristics of surface water at the area surrounding up to $4 \mathrm{~km}$ from Narol industrial area, Gujarat have been studied during monsoon, premonsoon and post- monsoon period of 2015. [10] The results obtained during the course of present study, are given in the Table 2 to 5 and the data are compared with water quality parameters as per ISO 10500. Total four sites were selected for water sample collection for study. The first closest one is designated as pond-1 which is 0.6 $\mathrm{km}$ away from core industrial area $(\mathrm{ClA})$, followed by second site which is drainage canal $1.7 \mathrm{~km}$ away from CIA. Third sample collection site is pond-2, which is $3 \mathrm{~km}$ away from CIA and the last one is chandola lake which is $4 \mathrm{~km}$ away from CIA. The results suggest that the various parameters are depending upon the hydrochemistry of the study area and also on the effluents released from various industries at Narol. There is occasional overflow of treated effluent at some manholes of Mega Pipeline in GIDC area due to excess effluent discharge in Mega Pipeline. This is mainly due to illegal domestic sewage connections into Mega Pipeline and excess effluent discharge by Industrial Units in Narol area. The treated effluent from industries in Narol does not meet disposal norms. The physical factors such as $\mathrm{pH}$, alkalinity, conductivity etc. play a significant role in maintaining water quality. $\mathrm{pH}$ is a measure of the acid balance of a solution. $\mathrm{pH}$ is the value expressed as the negative logarithm of the hydrogen ion concentration. The $\mathrm{pH}$ of water affects the solubility of many toxic and nutritive chemicals. The $\mathrm{pH}$ values of water samples at various sampling stations during monsoon, pre-monsoon and post- monsoon periods of 2015 show a large variation. The $\mathrm{pH}$ of water samples of four sampling sites (Pond-1, Drainage canal, Pond-2 and Chandola Lake) during pre-monsoon, monsoon and post monsoon are fluctuating with seasons as well as with distance from industrial cluster. It is ranging from 2.86 to 7.0 in monsoon, from 2.03 to 7.2 in post monsoon and from 1.88 to 7.4 in pre-monsoon period. It is observed that the samples nearer to CIA are strongly acidic (Table-2) which may be due to acidic byproducts and leakage of acids from storage site. The acidic character decreases with the increase in distance from CIA. "Dissolved solids" refer to any minerals, salts, metals, captions or anions dissolved in water. This includes anything present in water other than the pure water $\left(\mathrm{H}_{2} \mathrm{O}\right)$ molecule and suspended solids. In general, the total dissolved solids concentration is the sum of the captions (positively charged) and anions (negatively charged) ions in the water. TDS observed very high (3400) at nearest site in pre-monsoon and lowest 233 at site-2 in monsoon season may be because of inflow of rain water. Electrical conductivity is the 
measure of total concentration of dissolved salts in water. When salts dissolve in water, they give off electrically charged ions that conduct electricity. Conductivity ranges from 2002 to 752 in monsoon, 2064 to 612 in post monsoon and 2017 to 603 in pre-monsoon. Dissolved oxygen refers to the level of free, non-compound oxygen present in water or other liquids. It is an important parameter in assessing water quality because of its influence on the organisms living within a body of water. DO ranges from 13.1 to $7.8,13.5$ to 7.7 and 11 to 7.5 in monsoon, post monsoon and premonsoon respectively. BOD is a chemical procedure for determining the amount of dissolved oxygen needed by aerobic biological organisms in a body of water to break down organic material present in a given water sample at certain temperature over a specific time period. BOD ranges between 10 and 3.3. COD is a measure of the capacity of water to consume oxygen during the decomposition of organic matter and the oxidation of inorganic chemicals such as ammonia and nitrite. COD measurements are commonly made on samples of waste waters or of natural waters contaminated by domestic or industrial wastes. COD ranges from 9.2 to $6.3,8.5$ to 6.8 and 8.1 to 6.9 in monsoon, post monsoon and pre-monsoon respectively. Maximum Total hardness 1300 was recorded at site 1 in pre-monsoon and lowest 478 at site 4 in monsoon season. Calcium hardness and magnesium hardness recorded more or less within the prescribed limit of 75-200. Alkalinity is the buffering capacity of a water body. It measures the ability of water bodies to neutralize acids and bases thereby maintaining a fairly stable $\mathrm{pH}$. Water that is a good buffer contains compounds, such as bicarbonates, carbonates, and hydroxides, which combine with $\mathrm{H}^{+}$ions from the water thereby raising the $\mathrm{pH}$ (more basic) of the water. Without this buffering capacity, any acid added to a lake would immediately change its $\mathrm{pH}$. Aquatic organisms get benefit from a stable $\mathrm{pH}$ value in their optimal range. To maintain a fairly constant $\mathrm{pH}$ in a water body, a higher alkalinity is preferable. High alkalinity means that the water body has the ability to neutralize acidic pollution from rainfall or basic inputs from wastewater. As the concentration of $\mathrm{CaCO}_{3}$ increases, the alkalinity increases and the risk of acidification decreases. Alkalinity, reported as $\mathrm{mg} / \mathrm{L} \mathrm{CaCO}_{3}$. Alkalinity at study sites ranges between 566 and 69 . Chlorides are salts resulting from the combination of the gas chlorine with a metal. Some common chlorides include sodium chloride $(\mathrm{NaCl})$ and magnesium chloride $\left(\mathrm{MgCl}_{2}\right)$. Chlorine alone as $\mathrm{Cl}_{2}$ is highly toxic and it is often used as a disinfectant. In combination with a metal such as sodium it becomes essential for life. Chloride ranges from 6245 to 198,6321 to 206 and 7745 to 213 in monsoon, post monsoon and pre-monsoon respectively. Fluorine is the strongest oxidizing agent. It occurs in natural waters as a free anion $\left(\mathrm{F}^{-}\right)$, undissociated hydrofluoric acid $(\mathrm{HF})$, and its complexes. The natural level of fluoride in uncontaminated fresh surface water is 1.0-1.5, although industrial activities can increase concentrations to toxic levels. Out of all the water quality parameters studied, fluoride content in the water sample is found to be highly dangerous and much above the prescribed limit. The fluoride content of water samples at various sampling sites during monsoon, pre-monsoon and post- monsoon periods of 2015 are found to be in the range 6.4 to $4.8,8.2$ to 4.9 and 10.2 to 5.0 respectively. The fluoride content decreases with the increase in distance from CIA. So, care should be taken to reduce 
the fluoride content to the optimum level of 1.0-1.5 as prescribed by ISO 10500. Total Nitrogen is a measure of all forms of nitrogen (organic and inorganic). Nitrogen is an essential plant element and is often the limiting nutrient in marine waters. Nitrate Nitrogen range observed was between 350 and 156 .

\section{CONCLUSION:}

Contamination of drinking water supplies from industrial waste is a result of various types of industrial processes and disposal practices. Industries that use large amounts of water for processing have the potential to pollute waterways through the discharge of their waste into streams and rivers, or by run-off and seepage of stored wastes into nearby water sources. Other disposal practices which cause water contamination include deep well injection and improper disposal of wastes in surface impoundments.

To aware every individual and their participations to protect human health for sustainable development, the study recommends an extensive research on surface water quality at the vicinity of every industrial cluster and its possible impact on living system.

Significance of the study-The study assessed the current status of water quality in Narol and it is hoped that the results of this study will assist the relevant industries and authorities in designing appropriate preventive measures to ensure that the water quality in the streams is improved.

\section{RECOMENDATIONS}

The results suggest that the effluents being discharged into the streams have considerable negative effects on the water quality in the receiving streams. With increased industrial activities, the load of nutrients and pollutants entering the receiving streams will continue to increase and further diminish the quality of water. Introduction of cost-effective cleaner production technologies must be enforced, such as on-site waste separation and reduction, and effluent recycling. It is therefore recommended that careless disposal of the wastes should be discouraged and there is need for each industry to install a waste treatment plant with a view to treat wastes before being discharged into the streams.

\section{REFERENCES:}

Alka L. Gupta, 2006: Analytical Chemistry”. Pragati Prakashan, Meerut.

Comprehensive Environmental Pollution Abatement Action Plan Vatva Industrial Cluster, Gujarat Gujarat Pollution Control Board Gandhinagar 2010 
Classification of water pollutants and effects on environment, Module 10, NPTEL,IIT Kharagpur Web Courses. 2016

Dara SS. A Textbook of Environmental Chemistry and Pollution control. S. Chand and Co., New Delhi. 2007.

Dey AK. Environmental Chemistry. New Age International (P) Ltd., New Delhi. 2006

Environmental action, a GPCB magazine, Gujarat pollution control board, An ISO-9001-2008 \& 140012004 certified organization.

M.M. Saxena, 1998: "Environmental Analysis Water, Soil and Air" Agro Botanica, Bikaner.

Kodarkar, 1995: Conservation of lakes. Indian Association of Aquatic Biologists (IAAB), Hyderabad, Publ. 3. PP: 1 - 82.

Standard method for the examination of water and waste water. Ed. 14, APHA, AWWA, WPCF. American Public Health Association, Washington, DC;1976

Water pollution in India-Ministry of environment and Forest, Public Account Committee (2014-15), Eighth report. 